\title{
SUBSTANTIATION OF SAFE USE OF DISINFECTANT "STERIZENT"
}

Surmasheva O.V., Babii V.F., Polka O.O., Chernysh O.O., Kondratenko O.Ye.

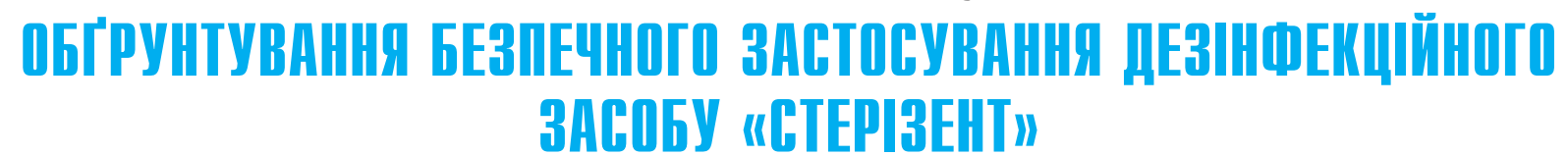

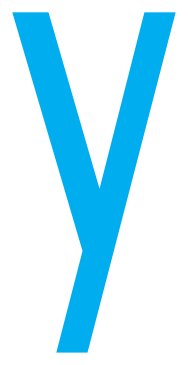

СУРМАШЕВА О.В., БАБІЙ В.Ф., ПОЛЬКА О.О., ЧЕРНИШ 0.0., КОНДРАТЕНКО О.Є. ДУ «Інститут громадського здоров'я ім. О.М. Марзєєва НАМН України», м. Київ зв'язку з надзвичайною загрозою пандемії COVID-19 в Україні наразі актуальним є використання ефективних дезінфекційних засобів (ДЗ) для розриву механізмів передачі збудника інфекції. Розвиток сучасних дезінфекційних технологій, використання ДЗ у лікувальнопрофілактичних закладах, у побуті та на виробництві дозволяють значно зменшити ризик виникнення та розвитку інфекцій. Проте залишається чимало питань щодо безпеки ДЗ для здоров'я людини та довкілля, визначення їхньої специфічної активності, розвитку резистентності мікроорганізмів до ДЗ, вибору адекватних режимів та методів обробки об'єктів з їх використанням для знезараження у вогнищах інфекційних захворювань, особливо в умовах пандемій та епідемій (що стосується також інфекції COVID-19), профілактич- ного використання тощо.

Ключовим питанням серед згаданих проблем є отримання об'єктивних даних щодо специфічної дії існуючих та нових розроблених дезінфекційних засобів. Адже відомо, що мікроорганізми, які належать до різних таксономічних груп, мають різну стійкість до антимікробних речовин, у тому числі й дезінфектантів.

Лише у 2020 році Наказом МО3 України № 2024 «Про затвердження Методів проведення досліджень специфічної активності, безпечності, якості (ефективності) дезінфекційних засобів та їх випробування на практиці», від 03.09.2020 р. прийнято нормативно-методичний документ, гармонізований з європейськими стандартами дослідження безпечності та ефективності дезінфекційних засобів для експертизи їх в Україні.
ОБҐРУНТУВАННЯ БЕЗПЕЧНОГО

ЗАСТОСУВАННЯ ДЕЗІНФЕКЦІЙНОГО

ЗАСОБУ «СТЕРІЗЕНТ»

Сурмашева О.В., Бабій В.Ф., Полька О.О., Черниш О.О., Кондратенко О.Є.

ДУ «/нститут громадського здоров'я ім. О.М. Марзєєва НАМН України», м. Київ

В умовах пандемії особливої актуальності набувають методи профілактики інфекційних захворювань, зокрема використання дезінфекційних засобів (ДЗ), для переривання механізмів передачі збудників інфекцій. Різноманіття ДЗ, представлених на сучасному ринку, дозволяє обрати найбільш адекватні меті, умовам та способам їх застосування. Проте основними критеріями вибору залишаються ефективність та безпека ДЗ для людини і довкілля. Тому особливу увагу привертають препарати, отримані методом електролізу (аноліти).

Мета: визначити бактерицидну, віруліцидну та дріжджецидну активність препарату «СТЕРИЗЕНТ» виробництва Ізраїль відповідно до сучасних вимог та стандартів.

Матеріалита методи. Дослідження специфічної активності ДЗ «СТЕРИЗЕНТ» проводилися згідно з Наказом МОЗ України № 2024 від 03.09.2020 р. та відповідно до європейських стандартів. У кількісному суспензійному методі використовували тест-культури та поживні середовища, рекомендовані Наказом № 2024 та стандартами EN 13727:2012+A2:2015 [3] i ДСТУ ЕN 13624: 2019 (EN 13624:2013, IDT). Віруліцидну активність досліджували на кишкових бактеріофагах T2 и MS2. Токсикологічні дослідження проводилися на тваринах згідно з сучасними стандартами.

Результати: було встановлено високу бактерицидну та дріжджецидну активність препарату «СТЕРИЗЕНТ» (Ізраїль) у нерозведеному вигляді з експозицією 30 с та 60 с для Escherichia coli K12 NCTC 10538 lg R>5,42, для Pseudomonas aeruginosa Ig $R>5,37$, для Staphylococcus aureus Ig $R>5,34$, для Candida albicans Ig R>4,31. У дослідженні з бактеріофагами з експозицією 30 с логарифми редукції становили T2 - >5,08, MS2 - >5, 12. За параметрами гострої токсичності засіб «СТEРИЗЕНТ» згідно з Наказом МОЗ України № 2024 з введенням у шлунок та нанесенням на шкіру належить до 4 класу - малонебезпечні речовини, з інгаляційним застосуванням у насичених концентраціях - до 3 класу, помірно небезпечні речовини. Препарат не виявляє сенсибілізаційної дії у рекомендованих режимах застосування.

Висновки. Отримані результати дозволяють рекомендувати препарат «СТЕРИЗЕНТ» ( (зраїль) для широкого практичного застосування як високоефективний, один з найменш токсичних ДЗ.

Ключові слова: дезінфекційні засоби, бактерії, гриби, віруси.

๑) Сурмашева О.В., Бабій В.Ф., Полька О.О., Черниш О.О., Кондратенко О.Є. СТАТТЯ, 2021.

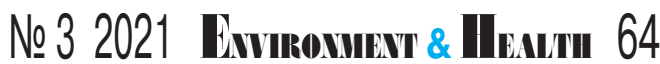


В умовах пандемії COVID-19 активізувалися виробництво та реєстрація дезінфекційних засобів, у тому числі антисептиків. Маючи у своєму складі хімічні речовини різного ступеня безпечності, ДЗ потребують різних умов і режимів застосування, оскільки іноді з ефективними концентраціями діючих речовин виникають небажані токсичні впливи на організм людини та довкілля. Зважаючи на це, перспективними є засоби, які отримують з застосуванням електролізу розчинів хлориду натрію. Одним 3 них є дезінфекційний засіб «СТЕРІЗЕНТ» (Ізраїль).

Мета дослідження - визначити бактерицидну, дріжджецидну та віруліцидну активність ДЗ «СТЕРІЗЕНТ» у суспензійному методі за сучасними вимогами, а також обґрунтувати умови безпечного використання засобу.

Матеріали та методи. Досліджуваний дезінфекційний засіб «СТЕРІЗЕНТ» виробництва Ізраїль $€$ розчином у вигляді прозорої безбарвної рідини 3 легким специфічним запахом хлору, рН 6,2-7,2. Склад засобу: хлорнуватиста кислота, високоактивні кисневі сполуки хлору, вільні радикали хлору та кисню ( $\mathrm{HClO} ; \mathrm{ClO}_{2} ; \mathrm{ClO}^{-}$; $\mathrm{O}_{3}^{+}$; $\mathrm{H}_{3} \mathrm{O}_{2}^{+} ; \mathrm{H}_{3} \mathrm{O}^{+} ; \mathrm{O}_{2} ; \mathrm{Cl}^{-}$); $\mathrm{NaCl}$; (масова концентрація активного хлору - 0,035\%). Сполуки активного хлору, перекисні сполуки, сполуки хлору перебувають у метастабільному (активованому) стані.

Окислювально-відновлювальний потенціал -1100-1300 мВ.

Засіб одержано методом електролітичної активації водного розчину $\mathrm{NaCl}$ в установці 3 використанням електрохімічних реакторів мембранного типу на базі проточних електрохімічних модульних елементів.

Тест-культури: Escherichia coli K12 NCTC 10538 (E. coli), Pseudomonas aeruginosa ATCC 9027 ( $P$. aeruginosa), Staphylococcus aureus ATCC 6538P (S. aureus), Candida albicans ATCC 10231 (C. albicans).

Для вивчення віруліцидної активності як модель застосовували соматичний ДНК-коліфаг T2 (Escherichia coli B (E. coli B) - як бактерія-хазяїн)

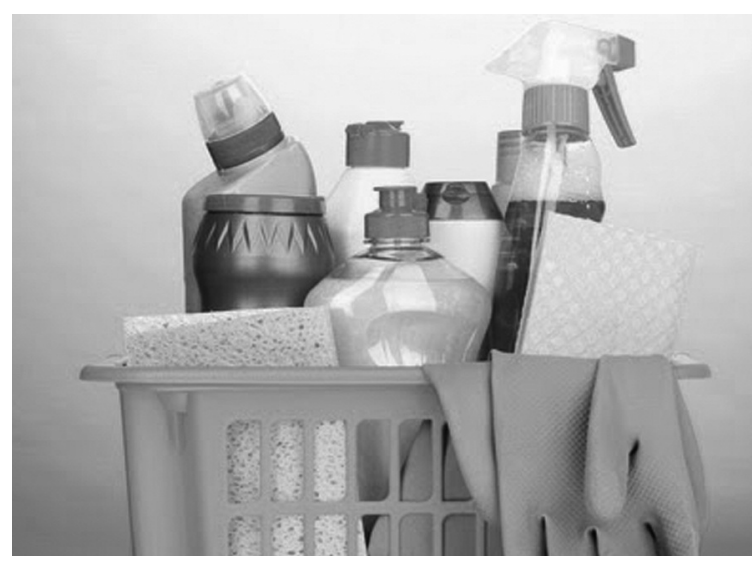

НОВІ ЗАСОБИ ДЕЗІНФЕКЦІї

і F-RNA коліфаг MS2 (E. coli K12 Hfr- як бактерія-хазяїн).

Поживні середовища. Щільне поживне середовище триптон-соєвий агар, виробництва «Biolife» (Італія) та щільне поживне середовище Сабуродекстрозний агар виробництва ТОВ «Фармактив» (Україна), ростові властивості та стерильність середовищ були перевірені перед початком досліджень.

Бичачий сироватковий альбумін (БСА) у концентрації 0,03\% було використано як інтерферуюча речовина «чисті умови».

Для нейтралізації залишкової дії активних компонентів розчинів вказаного засобу використовували метод мембранної фільтрації.

Визначення специфічної дезінфікційної дії. Зберігання та приготування тест-штамів для досліджень здійснювали згідно 3 Наказом МО3 України № 2024 «Про затвердження Методів проведення досліджень специфічної активності, безпечності, якості (ефективності) дезінфекційних засобів та їх випробування на практиці» від 03.09.2020 р. [1] та EN 12353:2006 [2].

Для визначення специфічної дезінфекційної дії відновлювали життєздатність ліофілізованих культур, перевіряли чистоту штамів та їхню ідентичність. Кількість клітин у вихідній суспензії визначали за оптичною густиною за довжини хвилі 620 нм у кюветі довжиною 10 мм 3 використанням фотоелектроколориметра (КФК-3).

Вивчення специфічної бактерицидної та дріжджецидної дії зразка дезінфекційного засобу «СТЕРІЗЕНТ» проводили кількісним суспензійним методом згідно з Наказом MO3 України № 2024, EN 13727: 2012+A2: 2015 [3] та ДСТУ ЕN 13624: 2019 (ЕN 13624: 2013, IDT)[4].

Принцип кількісного суспензійного методу полягав у тому, що досліджуваний розчин додавали до суміші робочої суспензії мікроорганізмів на обраний час експозиції 30 сек. та 60 сек. Після закінчення експозиції для нейтралізації залишкової дії активних компонентів використовували метод мембранної фільтрації. Фільтри переносили на щільне поживне середовище. Паралельно з випробуваннями ставили обов'язкові контролі, які відображали правильність методології та запобігали отриманню хибнопозитивних або хибнонегативних результатів. Використовували такі контролі:

вонтроль кількості мікроорганізмів (КУО/ $\left.\mathrm{CM}^{3}\right)$ у робочій тест-суспензії (N);

$\square$ експериментальних умов (A);

口 відсутності токсичності нейтралізатора (B);

$\square$ ефективності нейтралізації (C).

Кількість мікроорганізмів у робочій тест-суспензії (N) контролювали шляхом висіву на щільне поживне середовище у десятиразових розведеннях 10-6 та 10-7 для бактерій E. coli, $P$. aeruginosa, S.aureus, $10^{-5}$ та 10-6 для дріжджів C. albicans.

3 проведенням інших вказаних контролів використовували валідаційну суспензію (Nv) з вмістом мікроорганізмів від $\left(3,0 \times 10^{2}\right)$ до $\left(1,6 \times 10^{3}\right) \mathrm{KУO} / \mathrm{cm}^{3}$.

Вважали, що засіб володіє специфічною активністю у заданих умовах у кількісному суспензійному методі за середньої редукції не менше 5 lg для бактерій, не менше 4 lg для дріжджів.

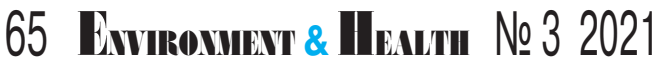


Для культивування тест-штамів та проведення всіх експериментів було використано однакові поживні середовища, ростові властивості та стерильність яких перевірялися перед початком досліджень.

Зберігання та приготування тест-штамів бактерій та кишкових фагів для досліджень здійснювали згідно з ДСТУ ЕN 13610: 2019 (EN13610:2002, IDT) [5] та MB 10.2.1-113-2005 «Санітарно-мікробіологічний контроль якості питної води» [6].

Кількість бактеріофагів у вихідній суспензії з використанням суспензійного методу становила від $\left(1,5 \times 10^{8}\right)$ до $(5,0 x$ 108) бляшкоутворювальних одиниць в $1 \mathrm{~cm}^{3}\left(\right.$ БУО $\left./ \mathrm{cm}^{3}\right)$ (8,17-8,70 lg).

Посіви інкубували за температури $(36 \pm 1) \circ \mathrm{C}$ протягом (4+2) годин, після чого чашки 3 посівами виймали з термостату і залишали у темному місці за кімнатної температури на $(18+2)$ год. (за необхідності).

Інтерферуючу речовину (бичачий сироватковий альбумін - БСА - фракції V) у дослідах для фагів не використовували.

Специфічну активність ДЗ у заданих умовах визначали за середнім значенням редукції.

Для визначення безпеки для здоров'я людини досліджували наступні токсиколого-гігієнічні показники:

гостра токсичність 3 введенням у шлунок;

$\square$ гостра токсичність з нанесенням на шкіру; дія;

$\square$ шкірно-подразнювальна

$\square$ сенсибілізаційна дія;

口 подразнювальна дія на слизову оболонку очей;

$\square$ оцінка летких компонентів засобу у насичених концентраціях парів.

Токсикологічні дослідження проводилися відповідно до сучасних вимог та стандартів [7-10]. Експериментальні дослідження виконувалися на трьох видах тварин - лабораторних мишах, мурчаках та кролях, що утримувалися в умовах віварію на збалансованому раціоні 3 вільним доступом до води.

Визначення параметрів небезпеки летких компонентів під час інгаляції здійснювали у статичному режимі затруєння в умовах максимально досяжних насичених концентрацій 3 вільним випаровуванням летких фракцій речовин.

Гостру токсичність визначали шляхом одноразового внутрішньошлункового введення засобу за допомогою спеціальних металевих зондів.

Оцінка стану тварин проводилася за інтегральними показниками токсичної дії: випадками загибелі, зовнішнім виглядом, загальним станом, особливостями поведінки, клінічними ознаками інтоксикації, інтенсивністю та характером рухової активності.

Подразнювальна дія засобу на слизову оболонку очей визначалася шляхом його внесення у кон'юнктивальний мішок кроля. Реакцію слизової оболонки оцінювали за клінічними ознаками - появою виділень із ока, ін'єкцією судин склери, почервонінням та набряком кон'юнктиви, помутнінням рогівки.

Гостру токсичність 3 нанесенням на шкіру визначали шляхом нанесення одноразових аплікацій на підготовану ділянку шкіри.

Сенсибілізаційну дію визначали шляхом нанесення шкірних проб з подальшим проведенням провокаційних проб.

Статистична обробка результатів експериментів проводилася за методом Ст'юдентаФішера. Достовірним вважали результати з $\mathrm{P}<0,05$.

Результати та їх обговорення. Дезінфекційний засіб «СТЕРІЗЕНТ», продукт анодної обробки водного розчину $\mathrm{NaCl}$ в електролітичній установці, $є$ результатом розвитку одного 3 найбільш прогресивних напрямків дезінфектології - активації дезінфекційних засобів.

у процесі електрохімічної активації низькоконцентрованого розчину хлориду натрію в електролітичних установках типу СТЕЛ та їхніх аналогах утворюються аноліт та католіт, що мають окислювальні та відновлювальні властивості, а також нейтральний аноліт АНК, що має унікальну біоцидну дію, поєднуючи мийні, дезінфекційні та стерилізаційні властивості.
Електрохімічно активовані (ЕХА) розчини мають широкий спектр дії на мікроорганізми. На відміну від традиційних дезінфекційних і стерилізаційних розчинів (глутаровий альдегід, формальдегід, хлорамін, дихлорізоцианурати, надоцтова кислота, четвертинні амонієві сполуки, сполуки важких металів та інших синтетичних біоцидних речовин) дійові компоненти нейтральних анолітів не $\epsilon$ ксенобіотиками і не виявляють шкідливого впливу на організм людини і теплокровних тварин. Ці речовини є неорганічними, які існують короткий період часу, високоактивні метастабільні хлоркисневі та гідропероксидні сполуки, подібні яким зазвичай синтезуються в організмі людини і теплокровних тварин спеціалізованими електрохімічно активними ферментами клітин і беруть участь у процесах нейтралізації шкідливих і чужорідних речовин в організмі.

Мікроорганізми не продукують таких речовин у процесі життєдіяльності і не мають систем антиоксидантного захисту, тому EXА біоцидні розчини є для них високотоксичними. Низька мінералізація ЕХА-розчинів та їхня підвищена гідратаційна здатність збільшують проникність клітинних стінок і мембран, відбувається інтенсивний переніс оксидантів, що веде до пригнічення ферментних систем бактеріальної клітини та її загибелі. Розроблені модифікації анолітів не спричиняють корозії металевих виробів за їх холодної стерилізації а також завдяки низький мінералізації (1,5-5,0 г/л) не накопичуються у пористих матеріалах після використання та висихання.

Продукт електролізу активованого водного розчину хлориду натрію (аноліт $3 \mathrm{pH}$, близьким до нейтрального) нині застосовується для дезінфекції та стерилізації у деяких країнах світу.

Результати дослідження бактерицидної та дріжджецидної дії зразка дезінфекційного засобу «СТЕРІЗЕНТ» у «чистих» умовах за температури $20^{\circ} \mathrm{C}$ та 3 експозицією 30 сек. і 60 сек. наведено у таблиці 1. 
SUBSTANTIATION OF SAFEUSE

OF DISINFECTANT «STERIZENT

Surmasheva O.V., Babii V.F., Polka O.O., Chernysh 0.O., Kondratenko O.Ye.

SI «O.M. Marzieiev Institute for Public Health NAMS of Ukraine», Kyiv

Under conditions of the pandemic, the methods for the prevention of infectious diseases, especially a use of the disinfectants (DS), in particular, are of special relevance in order to break the mechanisms of the transmission of infectious agents. The variety of DS, presented at the modern market, allows us to choose the most appropriate ones for the purposes, conditions and methods of application. However, the effectiveness and safety of the DS both for humans and the environmentare still the main choice criteria. In this regard, electrolysis preparations (anolytes) attract a special attention.

Objective: We determined the bactericidal, virucidal and yeast activity of the STERISENT preparation (Israel) according to modern requirements and standards.

Materials and methods: Studies of the specific activity of the DS "STERISENT" were carried out in accordance with the Order of the Ministry of Health of Ukraine No. 2024, 03.09.2020 and the European standards. The test cultures and culture media recommended by the Order No. 2024 and the standards EN 13727: $2012+$ A2: 2015 [3] and DSTU EN 13624: 2019 (EN 13624: 2013 ,
IDT) were used in the quantitative suspension method. Virucidal activity was studied in the intestinal bacteriophages T2 and

MS2. Toxicological studies were carried out in the laboratory animals in accordance with modern standards.

Results: Ahigh bactericidal and yeast-killing activity of STERISENTpreparation (Israel) in undiluted form was established for Escherichia coli K12 NCTC 10538 lg R>5.42, for

Pseudomonas aeruginosa Ig $R>5.37$; for Staphylococcus aureus Ig $R>5$.34; for Candida albicans $\lg R>4.31$ at exposure of $30 \mathrm{~s}$ and $60 \mathrm{~s}$ In the study in bacteriophages at an exposure of $30 \mathrm{~s}$, the logarithms of the reduction were: T2 - >5.08, MS2 - >5.12. According to Order № 2024 of Ministry of Health of Ukraine, by the parameters of acute toxicity, STERIZENT preparation belongs to class 4 - low-hazardous substances when administered to the stomach and applied to the skin; at the inhalation application in saturated concentrations - to class 3, moderately dangerous substances. The preparation does not have a sensitizing effect in the recommended modes of application.

Conclusions: The obtained results make it possible to recommend the STERISENT preparation (Israel) for wide practical use as a highly effective and one of the least toxic DS.

Keywords: disinfectants, bacteria, fungi, viruses.
Встановлено, що зразок ДЗ «СТЕРІЗЕНТ» виявляв високу бактерицидну активність 3 експозицією 30 сек. та 60 сек. щодо тест-штамів мікроорганізмів, для бактерій логарифм редукції становив >5,34-5,42; для дріжджеподібних грибів $>4,31$.

Усереднені результати дослідження віруліцидної активності засобу «СТЕРІЗЕНТ» 3 експозицією 30 сек. наведено у таблиці 2.

Проведені експериментальні дослідження демонструють, що ДЗ «СТЕРІЗЕНТ» $з$ застосуваням у нерозведеному стані та 3 експозицією 30 сек. є ефективним дезінфектантом для знезараження вірусів, про що свідчать високі логарифми редукції бактеріофагів: Т2 $>$ 5,08, MS2 - > 5,12.

Токсикологічні дослідження. Гостра токсичність з введенням у шлунок. Як експериментальних тварин використовували білих лабораторних мишей масою $(22 \pm 2)$ г. Розрахунок параметрів гострої токсичності засобу проводився за методом пробіт-аналізу кривих летальності Літчфілда та Вілкоксона у модифікації Н.А. Толоконцева та В.Б. Прозоровського.

Таким чином, згідно з Наказом МO3 [1] за параметрами гострої токсичності засіб належить до IV класу небезпечності (малонебезпечні речовини).

Гостра токсичність з нанесенням на шкіру. Гостра перкутанна токсичність визначалася шляхом одноразового затруєння статевозрілих мурчаків-самців світлої масті вагою 358-388 г. Засіб дезінфекційний у нативному стані наносили на ділянку шкіри площею 5 ×4 см, що становило дозу понад 2500 мг/кг. Токсичну дію оцінювали за клінічною картиною отруєння та загибеллю тварини.

У результаті експерименту не виникло будь-яких патологічних реакцій шкіри, змін у поведінці тварин, летальних випадків.

Отже, згідно з Наказом МО3 [1] за параметрами гострої токсичності 3 нанесенням на шкіру засіб належить до IV класу небезпечності (малонебезпечні речовини).
Визначення токсичної дії на слизову оболонку ока. Проводилося на 5 кролях породи «Шиншила» вагою 2,32,7 кг.У кон'юнктивальний мішок правого ока вносили по 30 мг речовини, ліве око слугувало контролем. Видимих ознак подразнення не спостерігалося

Відповідно до Наказу МО3 [1] за параметрами токсичної дії на слизову оболонку ока засіб належить до IV класу небезпечності (малонебезпечні речовини).

Визначення сенсибілізаційної дії. Обрали мурчаків як лабораторних тварин, найчутливіших до дії хімічних алергенів. Для сенсибілізації тварин у зовнішню поверхню вуха вводили внутрішньошкірно 200 мкГ засобу. Потім для проведення шкірних проб вводили внутрішньошкірно по 0,1 мл засобу на тварину. Шести контрольним тваринам аналогічно ввели по 0,1 мл дистильованої води. Облік реакцій здійснювали за 20 хвилин - для виявлення алергії негайного типу та за 24 і 48 годин - для виявлення алергії повільного типу. У двох мур- 
чаків у місці ін'єкції виникло почервоніння та незначні припухлості, однак такі реакції спостерігались і у контрольній групі - тобто це могло бути подразнення від уколу. У інших чотирьох тварин жодних симптомів подразнень не спостерігали. Сенсибілізаційна дія відсутня.

Визначення токсичності летких компонентів засобу. Експериментальні дослідження проводили на білих безпородних лабораторних мишах вагою (22 2 ) г. Режим затруєння: статичний, в ексикаторах протягом 2 годин (час насичення в ексикаторах - 1 доба), за температури $(21 \pm 2)^{\circ} \mathrm{C}$, об'єм повітря - 8 дм $^{3}$ (не менше 2,0 дм³ на одну особину на годину). Маса досліджуваної речовини у нативному стані - 20 г. Час спостереження після затруєння - 3 доби.

За кілька хвилин після початку експерименту всі тварини починали збуджено рухатись. Після закінчення експерименту та вилучення із ексикаторів тварини приходили до норми протягом 20 хвилин. У подальшому летальних випадків, а також негативних змін у поведінці тварин не виявлено.
Індекс інгаляційної токсичності - 0 балів.

Таким чином, за параметрами гострої токсичності засіб «CTEPIЗЕНТ» згідно з Наказом MO3 [1] з введенням до шлунка та нанесенням на шкіру належить до 4 класу - малонебезпечні речовини; у разі інгаляційного застосування у насичених концентраціях - до 3 класу, помірно небезпечні речовини. Препарат не виявляє сенсибілізаційних властивостей у рекомендованих режимах застосування. За даними літератури, подібні засоби не мають мутагенних та кумулятивних властивостей.

Отримані результати дозволяють рекомендувати ДЗ «СТЕPIЗЕНТ» до широкого практичного застосування, оскільки він має значні переваги перед багатьма дезінфектантами: відсутність токсичності розчинів робочих концентрацій, високий антивірусний, бактерицидний та антигрибковий ефект.

Слід також зазначити, що електрохімічно-активовані розчини мають нетривалий час існування, під час їх розпаду не утворюються токсичні для людини та довкілля речовини.

Таблиця 1

Результати дослідження бактерицидної та дріжджецидної активності ДЗ «СТЕРІЗЕНТ" У суспензійному тесті у «чистих умовах» з різним часом контакту, R Ig

\begin{tabular}{|l|c|c|c|c|}
\hline \multicolumn{1}{|c|}{$\begin{array}{c}\text { Тест-культура } \\
\text { мікроорганізмів }\end{array}$} & $\begin{array}{c}\text { Контроль } \\
\text { культури, } \mathrm{N}_{0}\end{array}$ & $\begin{array}{c}\text { Дослід, } \\
\text { Na }\end{array}$ & $\begin{array}{c}30 \\
\text { сек. }\end{array}$ & $\begin{array}{c}60 \\
\text { сек. }\end{array}$ \\
\hline $\begin{array}{l}\text { Escherichia coli K12 } \\
\text { NCTC 105 }\end{array}$ & 7,57 & $<2,15$ & $>5,42$ & $>5,42$ \\
\hline $\begin{array}{l}\text { Pseudomonas aeruginosa } \\
\text { ATCC 9027 }\end{array}$ & 7,52 & $<2,15$ & $>5,37$ & $>5,37$ \\
\hline $\begin{array}{l}\text { Staphylococcus aureus } \\
\text { ATCC 6538P }\end{array}$ & 7,49 & $<2,15$ & $>5,34$ & $>5,34$ \\
\hline Candida albicans ATCC 10231 & 6,46 & $<2,15$ & $>4,31$ & $>4,31$ \\
\hline
\end{tabular}

Віруліцидна активність дезінфекційного засобу Таблиця 2 "СТЕРІЗЕНТ" відносно кишкових бактеріофагів з експозицією 30 сек., $\mathbf{R}$ Ig

\begin{tabular}{|c|c|c|c|c|}
\hline $\begin{array}{c}\text { Кишковий } \\
\text { бактеріофаг }\end{array}$ & $\begin{array}{c}\text { Контроль } \\
\text { культури, } \mathrm{N}_{0}\end{array}$ & $\begin{array}{c}\text { Дослід, } \\
\mathrm{Na}\end{array}$ & $\begin{array}{c}\text { Редукція, } \\
\mathrm{R} \mathrm{Ig}\end{array}$ & $\begin{array}{c}\text { Редукція, середнє } \\
\text { значення }\end{array}$ \\
\hline \multirow{3}{*}{ T2 } & 7,28 & $<2,15$ & $>5,13$ & \multirow{2}{*}{$>5,08$} \\
\cline { 2 - 4 } & 7,24 & $<2,15$ & $>5,09$ & \multirow{2}{*}{$>$} \\
\cline { 2 - 4 } & 7,17 & $<2,15$ & $>5,02$ & \\
\hline \multirow{3}{*}{ MS2 } & 7,22 & $<2,15$ & $>5,07$ & \multirow{2}{*}{$>5,12$} \\
\cline { 2 - 4 } & 7,32 & $<2,15$ & $>5,17$ & \\
\cline { 2 - 4 } & 7,28 & $<2,15$ & $>5,13$ & \\
\hline
\end{tabular}

Засіб дезінфекційний «СТЕРІЗЕНТ» доцільно рекомендувати для дезінфекції приміщень у лікувально-профілактичних закладах, шкіри рук медичного персоналу, шкіри операційного поля, санітарнотехнічного обладнання, посуду, білизни, виробів медичного призначення, предметів догляду за хворими, прибирального інвентаря тощо при інфекціях бактеріальної (у т.ч. туберкульоз), грибкової (кандидози, дерматомікози) і вірусної етіології (у т.ч. гепатити, короновірусна інфекція, СНІД тощо); для передстерилізаційної обробки виробів медичного призначення у лікувально-профілактичних закладах; проведення поточної та заключної дезінфекції в осередках інфекційних хвороб, квартирах, дитячих закладах тощо; дезінфекції питної води та води плавальних басейнів, повітря приміщень; для дезінфекції та санітарної обробки приміщень, інвентарю, обладнання у харчовій і переробній промисловості (м'ясопереробній, молочній, пиво-безалкогольній, кондитерській галузях); у сільському господарстві; на підприємствах громадського харчування та торгівлі; на комунальних об'єктах (спортивно-оздоровчі комплекси, аптеки, перукарні, косметичні салони, вокзали, готелі, кінотеатри, сауни, туалети тощо); на різних транспортних засобах.

\section{Висновки}

1. В експериментальних дослідженнях бактерицидної та дріжджецидної активності дезінфекційного засобу «СТЕРІЗЕНТ» (Ізраїль) згідно з Наказом МОЗ України № 2024 «Про затвердження Методів проведення досліджень специфічної активності, безпечності, якості (ефективності) дезінфекційних засобів та їх випробування на практиці від 03.09.2020 р. встановлено, що дезінфекційний засіб «СТЕРІЗЕНТ» проявляв високу бактерицидну та дріжджецидну активність у нативному стані з експозицією 30 сек. та 60 сек. для Escherichia coli K12 NCTC 10538 lg R>5,42, для Pseudomonasaeruginosa Ig 
ОБОСНОВАНИЕ БЕЗОПАСНОГО

ПРИМЕНЕНИЯ ДЕЗИНФИЦИРУЮЩЕГО

СРЕДСТВА «СТЕРИЗЕНТ»

Сурмашева Е.В., Бабий В.Ф., Полька Е.А., Черныш E.A., Кондратенко E.E.

ДУ «Институт общественного здоровья им. А.Н. Марзеева НАМН Украины», Г. Киев

В условиях пандемии особую актуальность приобретают методы профилактики инфекционных заболеваний, в особенности использование дезинфицирующих средств (ДС), для прерывания механизмов передачи возбудителей инфекций. Разнообразие ДС, представленных на современном рынке, позволяет выбрать наиболее адекватные целям, условиям и способам применения. Однако основными критериями выбора остаются эффективность и безопасность ДС как для человека, так и для окружающей среды.

В связи с этим особое внимание привлекают препараты, полученные методом электролиза (анолиты).

Цель: определить бактерицидную, вирулицидную и дрожжецидную активность препарата «СТЕРИЗЕНТ» производства Израиль согласно современным требованиям и стандартам.

Материалы и методы. Исследования специфической активности ДС «СТЕРИЗЕНТ» проводились согласно Приказу Минздрава Украины № 2024 от 03.09.2020 г. и в соответствии с европейскими стандартами. В количественном суспензионном методе использовались тест-культуры и питательные среды, рекомендованные Приказом № 2024, стандартами EN 13727:2012+A2:2015 [3] и ДСТУ EN 13624: 2019 (EN 13624:2013, IDT).

Вирулицидную активность исследовали на кишечных бактериофагах T2 и MS2.

Токсикологические исследования проводились на лабораторных животных в соответствии с современными стандартами.

Результаты: была установлена высокая бактерицидная и дрожжецидная активность препарата «СТЕРИЗЕНТ» производства Израиль в неразведенном виде при экспозиции 30 с и 60 с для Escherichia coli K12 NCTC $10538 \mathrm{lg}$ $R>5,42$, для Pseudomonas aeruginosa Ig $R>5,37$; для Staphylococcus aureus Ig $R>5,34 ;$ для Candida albicans $\lg R>4,31$. В исследовании $c$ бактериофагами при экспозиции 30 с логарифмы редукции составили T2 - >5,08, MS2 $>5,12$. По параметрам острой токсичности средство «СТЕРИЗЕНТ» согласно Приказу Минздрава Украины № 2024 при введении в желудок и нанесении на кожу относится к 4 классу - малоопасные вещества; при ингаляционном применении в насыщающих концентрациях - к 3 классу, умеренно опасные вещества. Препарат не оказывает сенсибилизирующего действия в рекомендованных режимах применения.

Выводы. Полученные результаты позволяют рекомендовать препарат «СТЕРИЗЕНТ» производства Израиль к широкому практическому применению как высокоэффективное и одно из наименее токсичных ДС.

Ключевые слова: дезинфицирующие средства, бактерии, грибы, вирусы.
$\mathrm{R}>5,37$; для Staphylococcus aureus $\operatorname{lgR}>5,34$; для Candida albicans $\lg R>4,31$.

2. Проведені експериментальні дослідження демонструють, що ДЗ «СТЕРІЗЕНТ» 3 його застосуванням у нерозведеному вигляді та експозиції 30 сек. є ефективним дезінфектантом для знезараження від вірусів, про що свідчать високі логарифми редукції бактеріофагів: T2 - >5,08; MS2 $->5,12$.

3. За параметрами гострої токсичності засіб «СТЕРІЗЕНТ» згідно з Наказом МО3 [1] 3 введенням у шлунок та нанесенням на шкіру належить до 4 класу - малонебезпечні речовини; у разі інгаляційного застосування у насичених концентраціях - до 3 класу, помірно небезпечні речовини. Препарат не виявляє сенсибілізаційних, шкірно-резорбтивних, кумулятивних, мутагенних властивостей. Місцево-подразнювальну, шкірно-резорбтивну і сенсибілізаційну властивість засобу у рекомендова- них режимах застосування не виявлено.

4. Отримані результати дозволяють рекомендувати широке практичне застосування досліджуваного дезінфекційного засобу, який має значні переваги перед багатьма дезінфектантами: відсутність токсичності розчинів робочих концентрацій, високий антивірусний, бактерицидний та антигрибковий ефект, а також не потребує особливої утилізації після використання.

\section{ЛІТЕРАТУРА}

1. Про затвердження Методів проведення досліджень специфічної активності, безпечності, якості (ефективності) дезінфекційних засобів та їх випробування на практиці: Наказ МОЗ України № 2024; Чинний від 2020-0903. Режим доступу:

https://moz.gov.ua/article/ministry-mandates/nakaz-mozukraini-vid-03092020--2024pro-zatverdzhennja-metodivprovedennja-doslidzhen-specifichnoi-aktivnosti-bezpechnos- ti-jakosti-efektivnosti-dezinfekcijnih-zasobiv-ta-ih-viprobuvannja-na-praktici.

2. Chemical disinfectants and antiseptics - Preservation of microbial strains used for the determination of bactericidal and fungicidal activity: EN 12353. Режим доступу: https://standards.iteh.ai/catalog/standards/cen/82ada8f065f8-4ee7-aa6e-

946c12a1a673/en-123532021.

3. Засоби хімічні дезінфікувальні та антисептики.

Кількісний суспензійний метод оцінювання для визначення бактерицидної активності проти легіонели хімічних дезінфікувальних засобів для водних систем. Метод випробування та вимоги (етап 2, крок 1): ДСТУ ЕN 13623: 2019 (EN13623:2010, IDT) ; Чинний від 2019-08-01. Режим доступу: https://zakon.rada.gov.ua/ rada/show/v0176774-19\#Text

4.Засоби хімічні дезінфікувальні та антисептики.

Кількісний суспензійний

\section{Rovirovinest \& IIEMIII № 32021}


метод оцінювання для визначення фунгіцидної або псевдоактивності у медичній галузі. Метод випробування та вимоги (етап 2, крок 1): ДСТУ EN 13624: 2019

(EN13624:2013, IDT). Метод випробування та вимоги (етап 2, крок 1) ; Чинний від 201908-01. Режим доступу: https://zakon.rada.gov.ua/rada /show/v0176774-19\#Text

5. Хімічні дезінфікувальні засоби. Кількісний суспензійний метод оцінювання для визначення віруліцидної активності проти бактеріофагів хімічних дезінфікувальних засобів, використовуваних у закладах харчування та промисловості : ДСТУ ЕN 13610: 2019 (EN13610:2002, IDT); Чинний від 2019-08-01. Режим доступу: https://zakon.rada.gov.ua/rada /show/v0176774-19\#Text.

6. Санітарно-мікробіологічний контроль якості питної води : МВ 10.2.1-113-2005; Чинний від 2012-01-01. Режим доступу: https://zakon. rada.gov.ua/rada/show/v00044 88-10\#Text.

7. Державні санітарні правила і норми безпеки продукції парфумерно-косметичної промисловості: ДСанПіН 2.2.9.027-99. Режим доступу: https://zakon.rada.gov.ua/rada /show/v0027588-99\#Text.

8. OECD Principles of Good Laboratory Practice: OECD Environmental Health and Safety Publications ENV/MC/CHEM(98)17. Paris, 1998. 41p.

9. Принципы надлежащей лабораторной практики: ГОСТ P 53434-2000. М., 2000.

10. Резніков О.П. Загальні етичні принципи експериментів на тваринах. Ендокринологія. 2001. Т. 8. № 1. С. $142-145$.

\section{REFERENCES}

1. Pro zatverdzhennia Metodiv provedennia doslidzhen spetsyfichnoi aktyvnosti, bezpechnosti, yakosti (efektyvnosti) dezinfektsiinykh zasobiv ta yikh vyprobuvannia na praktytsi : Nakaz MOZ Ukrainy № 2024 vid 03.09.2020 [On the Adoption of the Methods for the

Performance of the Research of Specific Activity, Safety, Quality
(Efficiency) of the Disinfectants and Their Practical Tests: Order of the Ministry of Health of Ukraine № 2024, 03.09.2020 ]. URL: https://moz.gov.ua/article/ministry-mandates/nakazmoz-ukraini-vid-03092020-. 2024-pro-zatverdzhennjametodiv-provedennjadoslidzhen-specifichnoiaktivnosti-bezpechnosti-jakostiefektivnosti-dezinfekcijnihzasobiv-ta-ih-viprobuvannjana-praktici (in Ukrainian).

2. Chemical Disinfectants and Antiseptics - Preservation of Microbial Strains Used for the Determination of Bactericidal and Fungicidal Activity: EN 12353. URL : https://standards.iteh.ai/catalog/standards/cen/82ada8f0-65f84ee7-aa6e-946c12a1a673/en12353-2021.

3. Zasoby khimichni dezinfikuvalni ta antyseptyky. Kilkisnyi suspenziinyi metod otsiniuvannia dlia vyznachennia bakterytsydnoi aktyvnosti protylehionely khimichnykh dezinfikuvalnykh zasobiv dlia vodnykh system. Metod vyprobuvannia ta vymohy (etap 2, krok 1): DSTUEN 13623: 2019 (EN 13623:2010, IDT) [Chemical Disinfectants and Antiseptics. Quantitative Suspension Test for the Evaluation of Bactericidal Activity Against Legionella of Chemical Disinfectants for Aqueous Systems. Test Method and Requirements (Phase 2, Step 1) : DSTU EN 13623: 2019 (EN 13623:2010, IDT)]. URL : https://zakon.rada.gov.ua/rada /show/v0176774-19\#Text (in Ukrainian).

4. Zasoby khimichni dezinfikuvalni ta antyseptyky. Kilkisnyi suspenziinyi metod otsiniuvannia dlia vyznachennia funhitsydnoi abo psevdoaktyvnosti v medychnii haluzi. Metod vyprobuvannia ta vymohy (etap 2, krok 1): DSTU EN 13624: 2019 (EN 13624:2013, IDT). [Chemical Disinfectants and Antiseptics.Quantitative Suspension Test for the Evaluation of Fungicidal or Yeasticidal Activity in the Medical Area. Test Method and Requirements (Phase 2, Step 1) : DSTU EN 13624: 2019 (EN 13624:2013, IDT)]. URL: https://zakon.rada.gov.ua/rada
/show/v0176774-19\#Text

(in Ukrainian).

5. Khimichni dezinfikuvalni zasoby. Kilkisnyi suspenziinyi metod otsiniuvannia dlia vyznachennia virulitsydnoi aktyvnosti proty bakteriofahiv khimichnykh dezinfikuvalnykh zasobiv, vykorystovuvanykh u zakladakh kharchuvannia ta promyslovosti : DSTU EN 13610: 2019 (EN 13610:2002, IDT). [Chemical Disinfectants. Quantitative Suspension Test for the Evaluation of Virucidal Activity Against Bacteriophages of Chemical Disinfectants Used in Food and Industrial Areas. Test Method and Requirements (Phase 2, Step 1) :DSTU EN 13610: 2019 (EN 13610:2002, IDT)]. URL: https://zakon.rada. gov.ua/rada/show/v017677419\#Text

(in Ukrainian).

6. Sanitarno-mikrobiolohichnyi kontrol yakosti pytnoi vody : MV 10.2.1-113-2005 [Sanitaryand-Microbiological Control of Drinking Water Quality]. URL: https://zakon.rada.gov.ua/rada /show/v0004488-10\#Text (in Ukrainian).

7. Derzhavni sanitarni pravyla i normy bezpeky produktsii parfumerno-kosmetychnoi promyslovosti: DSanPiN 2.2.9.027-99 [State Sanitary Rules and Safety Standards for the Products of Perfumery and Cosmetic Industry: SSanRS 2.2.9.027-99]. URL:

https://zakon.rada.gov.ua/rada /show/v0027588-99\#Text

(in Ukrainian).

8. OECD Principles of Good Laboratory Practice: OECD Environmental Health and Safety Publications ENV/MC/CHEM (98) 17. Paris; $1998: 41 \mathrm{p}$.

9. Printsipy nadlezhashchey laboratornoy praktiki : GOST R 53434-2000 [Principles of Good Laboratory Practice : GOST R 53434-2000]. Moscow ; 2000 (in Russian).

10.Reznikov O.P. Zahalni etychni pryntsypy eksperymentiv na tvarynakh [General Ehic Principles of the Experiments in Animals]. Endokrynolohiia. 2001 ; 8 (1) : 142-145

(in Ukrainian).

Надійшло до редакції 12.02.2021 